\title{
The role of a 54-kb plasmid in the virulence of strains of Salmonella Enteritidis of phage type 4 for chickens and mice
}

\author{
H. HALAVATKAR and P. A. BARROW*
}

AFRC Institute for Animal Health, Houghton Laboratory, Houghton, Huntingdon, Cambridgeshire PE172DA*

\begin{abstract}
Summary. The role of a $54-\mathrm{kb}$ plasmid in the virulence of Salmonella Enteritidis strains of phage type 4 was examined in mice, young chickens and adult laying-hens. Although the plasmid was essential for full expression of virulence in mice, differences in expression of virulence by this $54-\mathrm{kb}$ plasmid were noted among strains; thus, introduction of the plasmid to a naturally occurring strain that lacked it did not make that strain virulent. In newly hatched chickens, virulence of an Enteritidis strain of phage type 4 by oral or parenteral routes was unrelated to possession of this plasmid which, similarly, played no role in infection in egg-laying hens. When a strain of Enteritidis phage type 4 and a plasmid-cured strain derived from it were given orally to chickens, both strains were equally invasive and their patterns of localisation in spleen, liver and ovaries were similar and they were isolated at similar frequencies from cultured, laid eggs.
\end{abstract}

\section{Introduction}

Enteritidis is the salmonella serotype most frequently associated with cases of food-poisoning in man. ${ }^{1}$ Many outbreaks traceable to sources of infection are derived from poultry and caused by strains of phage type 4 (PT4). In addition to their association with food-poisoning arising from broiler-carcase contamination as a result of faecal excretion, ${ }^{2}$ PT4 strains are highly virulent for young broiler chickens in which they cause considerable mortality ${ }^{3-5}$ they may also be isolated from laying flocks, ${ }^{6}$ and food-poisoning cases associated with consumption of eggs or other eggbased foods have been reported..$^{7-9}$ The extent to which egg contamination is a result of bacteria reaching individual ovules by haematogenous spread or of contamination, either in the oviduct or cloaca after formation of the egg, remains disputed. ${ }^{10-13}$ In a preliminary investigation of the virulence characteristics of Enteritidis strains for broiler chickens, PT4 strains showed greater virulence and invasiveness, and possibly persisted in faeces longer, than strains of PTs 6,8 or 13a. However, the actual virulence properties which allow PT4 strains to localise in the ovaries of infected chickens, and which have favoured their dissemination within the poultry industry, remain to be determined.

Large mol.-wt plasmids have been associated with virulence in strains of several host-adapted serotypes

Received 14 Jan. 1992; revised version accepted 30 July 1992.

* Present address: AFRC Institute for Animal Health, Compton Laboratory, Compton, Newbury, Berkshire RG16 0NN. that produce systemic typhoid-like disease in animals, e.g., Typhimurium, ${ }^{14}$ Enteritidis, ${ }^{15}$ Dublin, ${ }^{16}$ Gallinarum, ${ }^{17}$ Pullorum ${ }^{18}$ and Choleraesuis. ${ }^{19}$ There is considerable genetic ${ }^{17,20-23}$ and functional ${ }^{21.24}$ homology among plasmids of several of these serotypes. The role of a 54-kb plasmid in the virulence of Enteritidis strains has been studied in detail in mice only. ${ }^{11,15,25 .}$ Evidence of its importance in systemic disease in chickens is confusing. Thus, Nakamura et $a .^{15}$ indicated that, although the plasmid did not contribute to mortality in chickens, a plasmid-bearing strain from cattle was more invasive in chickens than a plasmid-cured strain derived from it; however, the latter strain was not tested after the plasmid had been re-introduced into it. In contrast, Hinton et al ${ }^{26}$ found that a plasmid-cured PT4 strain was no less invasive for chickens than its parent strain. In the present study, an attempt was made to resolve this confusion by examining in tests with mice, young chickens and adult laying-hens, the relative virulence of a PT4 strain, a plasmid-cured strain derived from it and one into which the plasmid was re-introduced. Again, the effect of introducing the 54-kb plasmid into a naturally occurring strain lacking it was also examined.

\section{Materials and methods}

\section{Bacteria and cultural conditions}

The Enteritidis strains of PT4 used in this study are shown in table I. Strains S1 and S31 were kindly supplied by Dr B. Rowe and Dr E. J. Threlfall, Central Public Health Laboratory, Colindale Avenue, 
London. All strains were stored on Dorset's egg slopes at $4^{\circ} \mathrm{C}$. Spontaneous (chromosomal) mutant strains resistant to nalidixic acid $\left(\mathrm{Nal}^{r}\right)$, spectinomycin $\left(\mathrm{Spec}^{r}\right)$ and rifampicin ( Rif $^{\top}$ ) were derived as described elsewhere. ${ }^{27} \mathrm{Nal}^{r}$ and Spec ${ }^{r}$ mutant strains of Salmonella are known to be no less virulent for chickens than their parent strains $^{2 i}$ (and P. A. Barrow, unpublished results). Bacterial cultures were grown in an orbital shaker at $200 \mathrm{rpm}$ in $\mathrm{L}$ broth $(10 \mathrm{ml}$, unless otherwise stated) for $16-18 \mathrm{~h}$ at $37^{\circ} \mathrm{C}$ to a density of $c .10^{9} \mathrm{cfu} / \mathrm{ml}$.

\section{Experimental animals}

Female BALB/c mice aged 6-8 weeks were used. Chickens were unsexed, day-old Rhode Island Red (RIR) obtained from a salmonella-free flock; their rearing conditions and diet have been described before. ${ }^{28}$ Pullets aged 16 weeks were obtained from a commercial flock, caged individually and used when c. 24 weeks old. Their freedom from salmonellae was checked bacteriologically. ${ }^{13}$

\section{Plasmid extraction and gel electrophoresis}

Plasmid DNA was isolated by a modification of the method of Kado and Liu. ${ }^{29}$ Briefly, $1.5 \mathrm{ml}$ of bacterial culture, grown at $37^{\circ} \mathrm{C}$ for $18 \mathrm{~h}$ with shaking, was centrifuged. To cell pellets, $200 \mu 1$ of lysis solution ( $50 \mathrm{~mm}$ Tris- $\mathrm{HCl}, \mathrm{pH} 8$, sodium lauryl sulphate $3 \%$, $30 \mathrm{~mm} \mathrm{NaOH}$ ) were added and incubated at $55^{\circ} \mathrm{C}$ for $30 \mathrm{~min}$. Lysed cells were extracted with equal volumes of Tris- $\mathrm{HCl}, \mathrm{pH} 8$, and saturated phenol-chloroform. The clear, upper aqueous phase was removed and electrophoresed in $0.045 \mathrm{~m}$ Tris-borate buffer with $0.001 \mathrm{~m}$ EDTA. on a horizontal agarose $0.6 \%$ gel for $5 \mathrm{~h}$ at $50 \mathrm{~V}$.

\section{Transposon mutagenesis and plasmid curing}

To assist in curing, the plasmid of strain $\mathrm{S} 1 \mathrm{Nal}^{r}$ was tagged with transposon Tn 3 encoding ampicillin resistance. This was achieved by phage P22-mediated transduction of the temperature-sensitive, tetracyclineresistance plasmid pSC101 containing Tn3, from Gallinarum strain $9^{17}$ to strain SINalr ${ }^{30.31}$ Plasmidcuring in the presence of acridine orange $1900 \mu \mathrm{g} / \mathrm{ml}$ was performed as described before. ${ }^{18}$

\section{Three-factor mating}

The 54-kb plasmid was re-introduced to plasmidcured derivative strains and introduced to naturally occurring strains that were devoid of plasmid by a three-factor mating in which the $54-\mathrm{kb}$ plasmid was mobilised by $\mathrm{F}$ factor present in a prototrophic $E$. coli K.12 strain. ${ }^{\text {is }}$

\section{Virulence tests and pathogenicity studies}

The pathogenesis of infection in mice has been described previously. ${ }^{24}$ The mortality produced by oral inoculation of newly hatched chickens, and LD50 estimations performed by intravenous injection into mice and intramuscular injection into chickens were assessed by methods described previously. ${ }^{17,24}$ Infection in 24-week-old hens was achieved essentially as described previously. ${ }^{13}$ Briefly, two groups of 11 and 12 hens, individually caged, were given an oral inoculum $(0.3 \mathrm{ml})$ of an undiluted broth culture of the $\mathrm{Nal}^{r}$ mutant strain $\mathrm{SINal}^{r}$, or of its plasmid-cured derivative strain $\mathrm{Sl}\left(\mathrm{pHH} 001^{-}\right) \mathrm{Nal}^{\mathrm{r}}$. Chickens were killed 1 and 2 weeks after challenge and organ samples were removed aseptically in the order of ovary, spleen and liver; cloacal swabs were taken and caecal contents were sampled. Ovary samples with ovules ruptured were enriched in Sodium Selenite Broth (Oxoid, CM395) and incubated overnight at $37^{\circ} \mathrm{C}$ before plating on Brilliant Green Agar (BGA) (Oxoid, CM263) containing nalidixic acid $20 \mu \mathrm{g} / \mathrm{ml}$ and novobiocin $1 \mu \mathrm{g} / \mathrm{ml}$. Other samples were homogenised in Dulbecco's phosphate-buffered saline (PBS, Oxoid BR 14a) in Griffith's tubes and estimations of viable counts of bacteria were made on antibiotic-containing BGA. ${ }^{32}$ Cloacal swabs were plated directly on antibiotic-containing BGA followed by enrichment in selenite broth. In the course of the experiment, all eggs laid by hens in each of the two groups were collected, care being taken not to cross-contaminate eggs from these two groups. Each egg was broken individually into a sterile glass jar along with its shell; the contents were mixed well, incubated overnight at $37^{\circ} \mathrm{C}$ and plated on antibiotic-containing BGA.

\section{Statistical analysis}

LD50 values were calculated with the Maximum Likehood Program (MLP) statistical package (AFRC Institute of Arable Crops Research, Rothamsted Experimental Station, Harpenden) which follows conventional methods of probit analysis. The procedure employs the conventional approach of assuming a parallel-line model. $\chi^{2}$ tests (Maximum Likehood) were extracted from the procedure to check parallelism and to compare LD50 values (comparison of intercepts in the procedure). This was not possible for some of the data presented in table II. In the latter case, the method of Reed and Muench ${ }^{33}$ was used. In table III, analysis of differences in mortality was performed by the $\chi^{2}$ test with $2 \times 2$ contingency tables. Analysis of differences in viable counts/g from samples (table IV) was performed by the Mann-Whitney test. Each of these tests was performed with the MINITAB statistical software (Minitab Inc., State College, PA, USA). In table IV, logistic linear-modelling analysis was used to determine differences in the number of eggs laid by hens contaminated or infected by each of the two strains; these tests were made with the GENSTAT statistical software (Rothamsted Experimental Station, Harpenden). 
Table I. Enteritidis strains of phage type 4 studied

\begin{tabular}{|c|c|c|}
\hline $\begin{array}{c}\text { Strain } \\
\text { designation }\end{array}$ & Description & $\begin{array}{l}54-\mathrm{kb} \\
\text { plasmid } \\
\text { content }\end{array}$ \\
\hline S1 & $\begin{array}{l}\text { Antibiotic-sensitive isolate from man (Amp", } \\
\text { Nals) }\end{array}$ & pHH0OI \\
\hline$\left.\mathrm{S} I \mathrm{Na}\right|^{r}$ & $\mathrm{Nal}^{r}$ mutant strain from strain $\mathrm{Sl}\left(\mathrm{Amp}^{s}, \mathrm{Nal}^{r}\right)$ & pHH0OI \\
\hline $\mathrm{S} I(\mathrm{Tn} 3) \mathrm{Nal}{ }^{r}$ & $\begin{array}{l}\text { Strain SINal }{ }^{r} \text { with pHH001 tagged with Tn3 } \\
\left(\mathrm{Amp}^{r}, \mathrm{Nal}^{r}\right)\end{array}$ & pHH001 ::Tn3 \\
\hline $\mathrm{Sl}\left(\mathrm{pHH} 001^{-}\right) \mathrm{Nal}^{\mathrm{r}}$ & $\begin{array}{l}\text { Strain S1 (Tn3) Nal }{ }^{\mathrm{r}} \text { cured of Tn3-labelled } \\
\text { plasmid by acridine orange }\left(\mathrm{Amp}^{s}, \mathrm{Nal}^{n}\right)\end{array}$ & $\ldots$ \\
\hline $\operatorname{Sl} 1(\operatorname{Tn} 3) \mathrm{Spec}^{r}$ & $\begin{array}{l}\text { Spec mutant strain from strain S1 } \\
\text { (pHH001-) Nal }{ }^{r} \text { with Tn3-labelled plasmid } \\
\text { introduced from Rif mutant of strain } \\
\text { Sl(Tn3)Nal }{ }^{r}\left(\mathrm{Amp}^{r}, \mathrm{Nal}^{r}, \mathrm{Spec}^{\mathrm{r}} \text { ) }\right.\end{array}$ & pHH001::Tn3 \\
\hline S31 & $\begin{array}{l}\text { Antibiotic-sensitive isolate from meat (Amp, } \\
\mathrm{Nal} \text {, }\end{array}$ & $\cdots$ \\
\hline S31 (pHH001+)Spec & $\begin{array}{l}\text { Spec mutant of strain S31 with tagged plasmid } \\
\text { introduced from Rifr mutant of strain } \\
\text { S1(Tn3)Nal" }\left(\mathrm{Amp}^{r}, \mathrm{Spec}^{r}\right)\end{array}$ & pHH001::Tn3 \\
\hline
\end{tabular}

Amp, ampicillin; Nal, nalidixic acid; Spec, spectinomycin; Rif, rifampicin; r, resistant; s, sensitive.

\section{Results}

\section{Plasmid analysis of strains}

The plasmid contents of the parent strain S1, its Tn3-labelled mutant strain, its plasmid-cured derivative strain and the two transconjugants $\mathrm{S} 1(\mathrm{Tn} 3) \mathrm{Spec}^{\mathrm{r}}$

Table II. LD50 values of Enteritidis strains in mice

\begin{tabular}{|c|c|c|c|c|}
\hline \multirow[b]{2}{*}{ Strain } & \multirow{2}{*}{$\begin{array}{l}\text { LD50 for mice } \\
\left(\log _{10} \mathrm{cfu}\right)\end{array}$} & \multicolumn{3}{|c|}{ Significance* } \\
\hline & & $\chi^{2}$ & d.f. $\dagger$ & $\mathrm{p}$ value \\
\hline SINalr ${ }^{r}$ & $1.31(\mathrm{SE} 0.27)$ & & & \\
\hline $\mathrm{Sl}(\mathrm{Tn} 3) \mathrm{Nal}^{\mathrm{r}}$ & 1.75 (SE 0.39) & $1 \cdot 1$ & 1 & $>0.05$ \\
\hline $\mathrm{Sl}\left(\mathrm{pHH} 001^{-}\right) \mathrm{Nar}^{r}$ & $5.5 t$ & & ND & \\
\hline S1(Tn3)Spect & $1.32(\mathrm{SE} 0.44)$ & 0.07 & 1 & $>0.05$ \\
\hline S31 & $5 \cdot 5+$ & & ND & \\
\hline S31(pHH001+ Spec $^{r}$ & $5 \cdot 5 t$ & & ND & \\
\hline
\end{tabular}

ND, not determined (for explanation, see text).

* Results for each of the derivative mutant strains are compared with those obtained with strain SiNal ${ }^{r}$.

+ Standard error could not be calculated.

Table III. Percentage mortality and LD50 values of Enteritidis strains for newly hatched chickens

\begin{tabular}{|c|c|c|c|}
\hline \multirow[b]{2}{*}{ Strain } & \multicolumn{2}{|c|}{ Mortality* } & \multirow[b]{2}{*}{$\begin{array}{c}\text { LD50 } \dagger \\
\left(\log _{10} \mathrm{cfu}\right) \ddagger\end{array}$} \\
\hline & $\begin{array}{l}\text { Number of } \\
\text { chickens } \\
\text { inoculated }\end{array}$ & $\begin{array}{l}\text { Number } \\
(\%) \text { dead }\end{array}$ & \\
\hline SiNal ${ }^{r}$ & 25 & $22(88)$ & $3.56(\mathrm{SE} 0.35)$ \\
\hline $\mathrm{Sl}(\mathrm{Tn} 3) \mathrm{Nal}^{\mathrm{r}}$ & 25 & $17(68)$ & ND \\
\hline $\mathrm{Sl}\left(\mathrm{pHH} 001^{-}\right) \mathrm{Nal}^{\mathrm{r}}$ & 24 & $20(83)$ & 2.91 (SE 0.32) \\
\hline S1(Tn3)Spec ${ }^{r}$ & 25 & $22(88)$ & 3.70 (SE 0.55) \\
\hline
\end{tabular}

ND, not determined.

* Percentage mortality was observed 3 weeks after chickens were experimentally infected orally with $10^{8}$ bacteria.

+ LD50 based on intramuscular injection of chickens.

$\ddagger$ Significant differences $(p>0.05)$ were not found in pairwisestrain comparisons of mortality or LD50 for either the intramuscular or oral route. and $\mathrm{S} 31\left(\mathrm{pHH}_{001^{+}}\right) \mathrm{Spec}^{\mathrm{r}}$ are shown (figure, lanes 3-6 and 8 ). The absence of $F$ plasmid from the transconjugants was confirmed by electrophoresis. Both of these transconjugants possessed smooth LPS, as judged by absence of agglutination with acriflavine and by agglutination with $\mathrm{O}$-specific antiserum.

\section{Virulence for mice}

The results of virulence tests with Enteritidis strains S1Nal ${ }^{\mathrm{r}}, \mathrm{S} 31$ and their derivatives (table I) made with $\mathrm{BALB} / \mathrm{c}$ mice are shown in table II. LD50 values of strain $\mathrm{S}_{1 \mathrm{Nal}^{\mathrm{r}}}$ and its Tn3-tagged derivative strain S1(Tn3) Nal ${ }^{r}$ were not significantly different. By contrast, both the plasmid-cured strain $\mathrm{S} 1\left(\mathrm{pHH}_{001^{-}}\right) \mathrm{Nal}^{r}$ and the naturally occurring plasmid-free strain S31 had much higher LD50 values. It was not possible to compare the LD50 values of strains $\mathrm{S} 1\left(\mathrm{pHH} 001^{-}\right) \mathrm{Nal}^{\mathrm{r}}$, S31 and S31 (pHH001 $\left.{ }^{+}\right)$Spec $^{r}$ with that of strain S1 Nal ${ }^{r}$ because of the absence of intermediate mortality values at bacterial doses around the LD50 value. However, calculated LD50 values were greater than the highest bacterial dose of $\mathrm{S} 1 \mathrm{Nal}^{\mathrm{r}}$ that did not produce $100 \%$ mortality $\left(10^{1} \mathrm{cfu}\right)$. Therefore, these differences were probably significant. Re-introduction of the Tn3labelled plasmid pHH001 to the plasmid-cured derivative strain $\mathrm{S} 1\left(\mathrm{pHH}_{001^{-}}\right) \mathrm{Nal}^{\mathrm{r}}$ restored the virulence of that strain; however, it did not increase the virulence of the naturally occurring plasmid-free strain S31. Similar results were obtained with another pHH001 :: Tn3 transconjugant of strain S31.

\section{Virulence for newly hatched chickens}

The virulence of Enteritidis strain S1Nal ${ }^{r}$ and its derivatives was assessed after oral and intramuscular inoculation of newly hatched RIR chickens; the results are shown in table III. Typical signs of salmonellosis including lethargy, anorexia, caked vents and emaciation were observed in all chickens after oral in- 
Table IV. Isolation of Enteritidis strains from the tissues of 22-week-old laying-hens

\begin{tabular}{|c|c|c|c|c|c|c|c|c|c|}
\hline \multirow[b]{3}{*}{ Strain } & \multirow{3}{*}{$\begin{array}{c}\text { Weeks } \\
\text { post- } \\
\text { inoculation }\end{array}$} & \multicolumn{3}{|c|}{ Median (range) $\log _{10}$ cfu/g in } & \multicolumn{5}{|c|}{$\begin{array}{c}\text { Number of samples positivet/number examined } \\
\text { with Enteritidis strains }\end{array}$} \\
\hline & & \multirow[b]{2}{*}{ liver } & \multirow[b]{2}{*}{ spleen } & \multirow{2}{*}{$\begin{array}{l}\text { caecal } \\
\text { contents }\end{array}$} & \multirow{2}{*}{$\begin{array}{l}\text { Cloacal } \\
\text { swabs }\end{array}$} & \multirow[b]{2}{*}{ Ovary } & \multicolumn{3}{|c|}{ Laid eggs } \\
\hline & & & & & & & Week 1 & Week 2 & Total $(\%)$ \\
\hline SINal' & 1 & $\begin{array}{c}2 \cdot 69^{*} \\
(2 \cdot 30.95)\end{array}$ & $\begin{array}{c}2 \cdot 74 \\
(2 \cdot 60-2 \cdot 95)\end{array}$ & $\begin{array}{c}5 \cdot 75 \\
(4.837 .00)\end{array}$ & $6 / 6$ & $6 / 6$ & $4 / 38$ & $\ldots$ & $\begin{array}{l}4 / 38 \\
(10 \cdot 5)\end{array}$ \\
\hline $\begin{array}{l}\text { Sl (pHHOOl }) \\
\text { Nal }^{r}\end{array}$ & 1 & $\begin{array}{c}2.96 \\
(2 \cdot 48-4 \cdot 08)\end{array}$ & $\begin{array}{c}3.08 \\
(<2-3 \cdot 87)\end{array}$ & $\begin{array}{c}7 \cdot 02 \\
(4 \cdot 38-9 \cdot 08)\end{array}$ & $3 / 6$ & $5 / 6$ & $9 / 43$ & $\ldots$ & $\begin{array}{l}9 / 43 \\
(20 \cdot 9)\end{array}$ \\
\hline SINal & 2 & $\begin{array}{c}<2 \\
(4 / 5)^{\dagger}\end{array}$ & $\begin{array}{c}2 \cdot 30 \\
(2 \cdot 00-3 \cdot 48)\end{array}$ & $\begin{array}{c}5.04 \\
(2.00-7.05)\end{array}$ & $2 / 5$ & $2 / 5$ & $4 / 26$ & $5 / 31$ & $\begin{array}{c}9 / 57 \\
(15 \cdot 7)\end{array}$ \\
\hline $\begin{array}{l}\mathrm{Sl}\left(\mathrm{pHHO01} 1^{-}\right) \\
\mathrm{Nal}^{\prime}\end{array}$ & 2 & $\begin{array}{l}<2 \\
(6 / 6)+\end{array}$ & $\begin{array}{c}2 \cdot 30 \\
(<2-4 \cdot 00)\end{array}$ & $\begin{array}{l}2 \cdot 23 \\
(N D-4.84)\end{array}$ & $2 / 6$ & $2 / 6$ & $6 / 36$ & $1 / 42$ & $\begin{array}{l}7 / 78 \\
(8 \cdot 9)\end{array}$ \\
\hline
\end{tabular}

* $\log _{11}$ median viable count/g from five or six chickens. $\log _{11}<2$. organism detected following enrichment culture. No significant differences $(p>0.05)$ were found in pairwise strain comparison of $\log _{\mathbf{1 0}} \mathrm{cfu} / \mathrm{g}$ of liver. spleen and caecal content during the period of observation.

+ By enrichment culture

Organisms not detected by enrichment culture.

oculation of Enteritidis PT4 strains. Some surviving chickens exhibited polyserositis involving the liver and pericardium. Significant differences were not seen either in the percentage mortality resulting from oral inoculation or in the LD50 after intramuscular injection with the parent strain $\mathrm{S}_{\mathrm{N}} \mathrm{Nal}^{\mathrm{r}}$ and its derivatives.

\section{Virulence for laying-hens}

To establish whether plasmid $\mathrm{pH} 001$ had a role in the pathogenesis of salmonella infection in adult hens, groups of 24-week-old laying hens were inoculated orally with strain S1 Nal ${ }^{r}$ or the plasmid-cured strain Sl $\left(\mathrm{pHH}_{001^{-}}\right) \mathrm{Nal}^{\mathrm{r}}$ derived from it. The presence of bacteria in different tissues was examined 1 and 2 weeks after inoculation; results showed the similar behaviour of these two strains (table IV). One week after inoculation the numbers of viable bacteria of strains $\mathrm{S}_{\mathrm{Nal}} \mathrm{Na}^{\mathrm{r}}$ and $\mathrm{Sl}\left(\mathrm{pHH} 001^{-}\right) \mathrm{Nal}^{r}$ isolated from liver, spleen and caecal contents were high. The values obtained with these strains were not significantly different. Bacteria were also isolated from cloacal swabs and ovaries of all hens infected with strain SINal' and from many of the samples from hens infected with strain $\mathrm{Sl}\left(\mathrm{pHH}_{001^{-}}\right) \mathrm{Nal}^{\mathrm{r}}$. By 2 weeks after inoculation, the numbers of salmonellae in liver, spleen and caeca had declined. In a few hens, cloacal swabs and ovaries were positive for both strains. The proportions of eggs infected or contaminated with either strain 1 week after injection were not significantly different; in the second week there seemed to be a significant difference in the proportion of infected eggs. However, the apparent significance of this result depended largely on the finding that there was one chicken in one of the groups that had laid two eggs, both of which were infected. Removal of this observation from the data-set produced a non-significant result when the comparison was repeated. This sug- gested that the apparent significance may have been a consequence of the small number of hens studied and that a larger sample might have produced more homogeneous data.

\section{Discussion}

This work has shown that, whilst the $54-\mathrm{kb}$ plasmid of a strain of Enteritidis of PT4 is essential for full expression of virulence in mice, it has no role in the

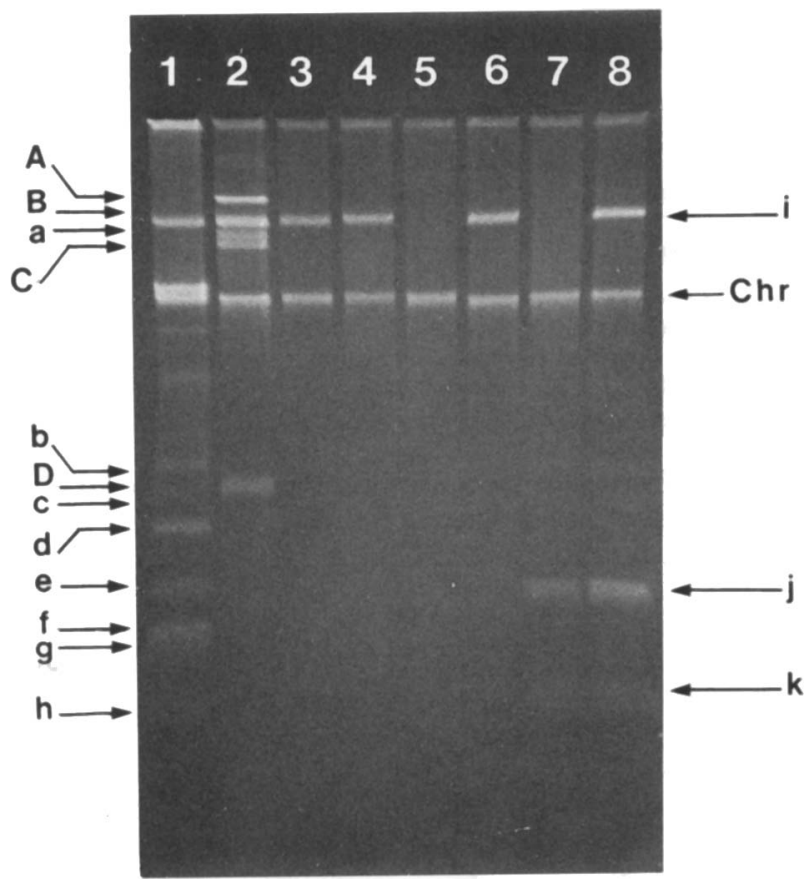

Figure. Agarose gel electrophoresis of plasmid DNA from E. coli and Enteritidis strains. Lane 1, plasmids of $\mathrm{M}_{\mathrm{r}}$ standards from E. coli strain V517 (a-h: 48, 7.8, 5.2, 4.5, 3.3, 2.5, 2.25 and $1 \cdot 8 \mathrm{~kb}) ; 2$ plasmids of $\mathrm{M}_{\mathrm{r}}$-standards from E. coli strain 39R861 (A-D: 147, 63, 35.8 , doublet $6.9 \mathrm{~kb}) ; 3-8$, Enteritidis strains: 3 , strain $\mathrm{S} 1 \mathrm{Nal}{ }^{\mathrm{r}} ; \mathbf{4}$, strain $\mathrm{S} I \mathrm{Nal}^{\mathrm{r}}$ with $\mathrm{Tn} 3$-labelled plasmid (i); 5 , plasmid-cured strain Sl (pHH001-) Nalr $; 6$, strain S1(Tn3)Spec $;$; , strain S31 carrying $3 \cdot 8-\mathrm{kb}(\mathrm{j})$ and $1 \cdot 2-\mathrm{kb}(\mathrm{k})$ plasmids; 8 , strain S31 with Tn3-tagged plasmid (i) re-introduced. $\mathrm{Chr}=$ chromosomal band. 
production of disease and death in newly hatched chickens or in the localisation of bacteria in the visceral organs, including the ovaries, after oral infection of laying-hens. The association between possession of the plasmid and virulence for mice has been reported by others for Enteritidis strains of PT4 and other strains. ${ }^{11,15,25}$ However, introduction of the virulence plasmid from one PT4 strain to another strain that lacked it naturally did not increase the virulence of the latter strain, as it did for the plasmid-cured derivative described above. The 54-kb plasmid is stable when introduced to naturally occurring strains that lack it and, since full expression of the ability to survive and multiply in the reticuloendothelial system has been found to involve both plasmid- and chromosomallymediated characteristics, ${ }^{24,34,35}$ it seems likely that strain S31 in this study lacked a full complement of functional chromosomal genes of virulence. A similar observation has been reported for some Typhimurium strains in which the level of virulence of naturally occurring plasmid-free strains was unaffected by the $90-\mathrm{kb}$ virulence plasmid of Typhimurium. ${ }^{36}$ There may be chromosomal genes that allow the $90-\mathrm{kb}$ plasmid of Typhimurium to express high virulence in highly virulent strains and some of these putative genes may be absent or mutated in some naturallyoccurring plasmid-free strains. The absence of the 54$\mathrm{kb}$ plasmid in some Enteritidis strains may result from plasmid loss, suggesting that chromosomal genes might affect long-term virulence-plasmid stability. Although the invasiveness of PT4 strains of Enteritidis in day-old chickens has been shown to be unrelated to the possession of the 54-kb plasmid, the role of the plasmid in virulence for chickens was not investigated. ${ }^{26}$ The results presented here demonstrate clearly that the 54-kb plasmid does not contribute to virulence of Enteritidis strains for day-old chickens. A similar

\section{References}

1. Report. The microbiological safety of food (part 1). London, HMSO. 1990.

2. Rampling A, Anderson JR, Upson R, Peters E, Ward LR, Rowe B. Salmonella enteritidis phage type 4 infection in broiler chickens: a hazard to public health. Lancet 1989; 2: 436.438.

3. Lister SA. Salmonella enteritidis infection in broilers and broiler breeders. Vet Rec 1988; 123: 350.

4. O'Brien JDP. Salmonella enteritidis infection in broiler chickens. Vet Rec 1988; $122: 214$.

5. Barrow PA. Experimental infection of chickens with Salmonella enteritidis. Avian Pathol 1991; 20: 145-153.

6. Hopper SA, Mawer S. Salmonella enteritidis in a commercial layer flock. Vet Rec 1988; 123: 351

7. Coyle EF, Palmer SR, Ribeiro CD et al. Salmonella enteritidis phage type 4 infection: association with hens' eggs. Lancet 1988; 2: 1295-1297.

8. Paul J, Batchelor B. Salmonella enteritidis phage type 4 and hens egg. Lancet 1988; 2: 1421

9. Report of the House of Commons Agriculture Committee. Salmonella in eggs. London, HMSO. 1989.

10. Bygrave AC, Gallagher J. Transmission of Salmonella enteritidis in poultry. Vet Rec $1989 ; 124: 571$.

11. Chart H, Threlfall EJ, Rowe B. Virulence of Salmonella enteritidis phage type 4 is related to the possession of a 38 MDa plasmid. FEMS Microbiol Lett 1989; 58: 299-304. observation has been made with a Typhimurium strain; thus, elimination of a $90-\mathrm{kb}$ plasmid led to a reduction in its virulence for mice but to a small increase in virulence for chickens (P. A. Barrow, unpublished results).

Bacteriological analysis of the tissues of laying-hens after experimental oral infection with Enteritidis strain $\mathrm{S} 1 \mathrm{Nal}^{\mathrm{r}}$ or $\mathrm{S} 1\left(\mathrm{pHH}_{001^{-}}\right) \mathrm{Nal}^{\mathrm{r}}$ revealed that the $54-\mathrm{kb}$ plasmid was not essential for bacterial localisation in a number of tissues, including the ovary. The low frequency of isolation of bacteria of the plasmid-cured strain from cloacal swabs may have been due to their intermittent excretion. The apparent absence of selective advantage of the plasmid for Enteritidis strains in the production of disease makes it conceivable that the plasmid confers an advantage by increased survival of bacteria in the environment including the faeces. This hypothesis would be worth studying. The microbial basis for the prevalence and persistence of Enteritidis strains of PT4 remains to be determined and it may involve a number of factors including invasiveness, intestinal colonisation, immunosuppression and survival in the environment. In an investigation of the genetic basis of virulence for chickens, it was essential to examine the role of the plasmid and this study shows that it was not important. In the pathogenesis of Typhimurium infection in newly hatched chickens, invasiveness was considered to be the virulence determinant of over-riding importance. Enteritidis strains are highly invasive for chickens, ${ }^{2.4 .5 .26}$ therefore, an investigation of this virulence characteristic might contribute to a greater understanding of the pathogenesis of avian infection by strains of this serotype.

This work was supported by a grant from the Ministry of Agriculture, Fisheries and Food. We thank Miss J. East for excellent technical assistance and $\mathrm{Mr} \mathrm{B}$. Wells for other assistance.

12. Humphrey TJ, Baskerville A, Chart H, Rowe B. Infection of egg-laying hens with Salmonella enteritidis PT4 by oral inoculation. Vet Rec 1989; 125: 531-532.

13. Barrow PA, Lovell MA. Experimental infection of egg-laying hens with Salmonella enteritidis phage type 4. Avian Pathol 1991; 20: 335-348.

14. Jones GW, Rabert DK, Svinarich DM, Whitfield HJ. Association of adhesive, invasive and virulent phenotypes of Salmonella typhimurium with autonomous 60-Megadalton plasmids. Infect Immun 1982; 38: 476-486.

15. Nakamura M, Sato S, Ohya T, Suzuki S, Ikeda S. Possible relationship of a 36-Megadalton Salmonella enteritidis plasmid to virulence in mice. Infect Immun 1985; 47: 831-833.

16. Terakado N, Sekizaki T, Hashimoto K, Naitoh S. Correlation between the presence of a fifty-Megadalton plasmid in Salmonella dublin and virulence for mice. Infect Immun $1983 ; 41$ : 443-444.

17. Barrow PA, Simpson JM, Lovell MA, Binns MM. Contribution of Salmonella gallinarum large plasmid toward virulence in fowl typhoid. Infect Immun 1987; 55: 388-392.

18. Barrow PA, Lovell MA. The association between a large molecular mass plasmid and virulence in a strain of Salmonella pullorum. J Gen Microbiol 1988; 134: 2307. 2316.

19. Kawahara K, Haraguchi Y, Tsuchimoto M. Terakado N Danbara $\mathrm{H}$. Evidence of correlation between 50-kilobase 
plasmid of Salmonella choleraesuis and its virulence. Microb Pathog 1988: 4: 155-163.

20. Popoff MY. Miras I, Coynalt C, Lasselin C. Pardon P. Molecular relationships between virulence plasmids of Salmonella serotypes typhimurium and dublin and large plasmids of other Salmonella serotypes. Ann Microbiol (Paris) 1984: 135: 389 398

21. Williamson CM. Baird GD, Manning EJ. A common virulence region on plasmids from eleven serotypes of Salmonella. $J$ Gen Microbiol 1988: 134: 975-982.

22. Korpela K. Ranki M. Sukupolvi S, Mäkelä PH. Rhen M Occurrence of Salmonella typhimurium virulence plasmidspecific sequences in different serovars of Salmonella. FEMS Microbiol Lett 1989; $58: 4954$

23. Woodward MJ, Mclaren I. Wray C. Distribution of virulence plasmids within Salmonellae. J Gen Microbiol 1989: 135 $503-511$.

24. Barrow PA, Lovell MA. Functional homology of virulence plasmids in Salmonella gallinarum. $S$. pullorum and $S$. typhimurium. Infect Immun 1989;57:3136-3141.

25. Hovi M, Sukupolvi S. Edwards MF. Rhen M. Plasmidassociated virulence of Salmonella enteritidis. Microb Pathog 1988: 4: 385-391.

26. Hinton M. Threlfall EJ, Rowe B. The invasiveness of different strains of Salmonella enteritidis phage type 4 for young chickens. FEMS Microbiol Lett 1990: 70: 193-196.

27. Smith HW. Tucker JF. The virulence of Salmonella strains for chickens; their excretion by infected chickens. $J$ Hyg 1980 ; 84: $479-488$.

28. Smith HW, Tucker JF. The effect of antibiotic therapy on the faecal excretion of Salmonella typhimurium by experimentally infected chickens. J Hyg 1975; 75: 275-292.

29. Kado CI, Liu S-T. Rapid procedure for detection and isolation of large and small plasmids. J Bacteriol 1981; 145 1365-1373.

30. Binns MM, Vaughan $\mathrm{S}$, Timmis $\mathrm{KN}$. ' $\mathrm{O}$ '-antigens are essential virulence factors of Shigella sonnei and Shigella dysenteriae 1. Zentralbl Bakteriol Mikrobiol Hyg (B) 1985; 181: $197-205$

31. Davis RW, Botstein D, Roth JR (eds). Advanced bacterial genetics. A manual for genetic engineering. Cold Spring Harbor, NY, Cold Spring Harbor Laboratory. 1980: 78.

32. Miles AA, Misra SS, Irwin JO. The estimation of the bactericidal power of blood. $J H y g 1938 ; 38: 732-749$.

33. Reed LJ, Muench H. A simple method of estimating fifty percent endpoints. $A m J H_{y g}$ 27: 493 497.

34. Fields PI, Groisman EA, Heffron F. A Salmonella locus that controls resistance to microbicidal proteins from phagocytic cells. Science 1989; 243 : 1059-1062.

35. Groisman EA, Saier MH. Salmonella virulence: new clues to intramacrophage survival. Trends Biochem Sci 1990; 15: 30-33.

36. Ou TJ, Baron L. Strain differences in expression of virulence by the $90-\mathrm{kb}$ pair virulence plasmid of Salmonella serovar typhimurium. Microb Pathog 1991; 10: 247-251. 